\title{
Induction of Cytokine Expression by Leukemia Inhibitory Factor
}

Peter M. Villiger, Yu Geng, and Martin Lotz

Sam and Rose Stein Institute for Research in Aging and the Department of Medicine, University of California, San Diego, La Jolla, California 92093

\begin{abstract}
Biological effects of cytokines are in part determined by their interactions in the regulation of cytokine production. This study analyzes the effects of leukemia inhibitory factor (LIF) on cytokine expression in different cell lineages. Recombinant human LIF increases levels of IL-1 $\beta$, IL-6, and IL-8 mRNA in human articular chondrocytes as demonstrated by Northern blotting. These cytokine mRNAs are detectable as early as 1.3 $h$ after stimulation and reach their maximum after $5 \mathrm{~h}$. The LIF effects are dose dependent and of similar magnitude to those of IL-1. By metabolic labeling and immunoprecipitation it is shown that LIF induces synthesis and secretion of IL-6. IL-6 bioactivity in conditioned media, as measured by the $\mathrm{B} 9$ hybridoma proliferation assay, is increased by LIF. Effects of LIF on cytokine expression are not confined to connective tissue cells. By PCR it is shown that human blood monocytes express IL-6 mRNA after stimulation with LIF. An increase in IL-6 mRNA levels is detectable $\mathbf{2} \mathrm{h}$ after stimulation, and this starts to decline by $5 \mathrm{~h}$. The response is of shorter duration as compared with IL-1 $\beta$. In addition to increased mRNA expression, LIF also stimulates release of biologically active IL-6 from blood monocytes. In synoviocytes and neuronal as well as epithelial cell lines, LIF increases IL-1 $\beta$ and IL-6 gene expression. In summary, LIF induces cytokine expression in a wide variety of tissues. These results suggest that through the induction of cytokines, LIF can modulate inflammation, immune responses, and connective tissue metabolism, and act as a pathogenetic mediator in different disease states. (J. Clin. Invest. 1993. 91:1575-1581.) Key words: leukemia inhibitory factor • cytokines • chondrocytes $\bullet$ monocytes
\end{abstract}

\section{Introduction}

A characteristic property of cytokines is their ability to regulate the expression of other cytokines, and this interaction can mediate or modulate the biological effects of a particular cytokine. Leukemia inhibitory factor (LIF) ${ }^{1}$ is a cytokine that was initially described on the basis of its ability to induce differentiation of murine myeloid leukemic cells (1). It inhibits differen-

Address correspondence to Dr. Martin Lotz, UCSD, La Jolla, CA 92093-0663.

Received for publication 18 May 1992 and in revised form $18 \mathrm{No}$ vember 1992

1. Abbreviations used in this paper: GAPDH, glyceraldehyde 3-phosphate dehydrogenase; LIF, leukemia inhibitory factor; MCP-1, monocyte chemoattractant protein-1; OSM, oncostatin M; SP, substance P.

J. Clin. Invest.

(c) The American Society for Clinical Investigation, Inc.

$0021-9738 / 93 / 04 / 1575 / 07 \$ 2.00$

Volume 91, April 1993, 1575-1581 tiation of pluripotent embryonal stem cells $(2,3)$, induces the synthesis of hepatic acute phase proteins (4), promotes neuronal differentiation (5-7), inhibits lipoprotein lipase activity (8), and regulates bone metabolism (9-11). LIF is produced by cells of the immune system (12-14), thymic epithelial cells, fibroblasts, endothelial cells, and rat liver cells (15-19). We recently identified human articular chondrocytes and synoviocytes as intraarticular sources of LIF (20) and showed that LIF is integrated into the cytokine network through its induction by IL-1 and TNF. This study shows that LIF shares with IL-1 and TNF the ability to induce cytokine production in different cell types.

\section{Methods}

\section{Cell isolation and culture}

Chondrocytes. Cartilage was obtained at autopsy or from the University of California, San Diego tissue bank from donors without known history of joint disease. For all experiments reported here, cartilage from the femoral condyles and tibial plateaus of the knee joints was used. Cartilage slices were prepared, washed with DMEM (Whittaker MAB Bioproducts, Walkersville, MD), minced with a scalpel, and treated with trypsin $(10 \% \mathrm{vol} / \mathrm{vol})$ for $15 \mathrm{~min}$ in a $37^{\circ} \mathrm{C}$ water bath. The samples were digested in DMEM containing 5\% FBS, penicillinstreptomycin-fungizone, and $2 \mathrm{mg} / \mathrm{ml}$ clostridial collagenase type IV (Sigma Immunochemicals, St. Louis, MO). The cells were washed three times and cultured as primary chondrocytes at high cell density ( 4 $\times 10^{6}$ cells per T175 flask).

Monocytes. PBMCs were isolated from heparinized blood by Ficoll-Hypaque density gradient sedimentation. Monocytes were isolated by adherence to gelatin-coated culture dishes that were preincubated with autologous plasma. The plates were washed to completely remove nonadherent cells. Puck's EDTA solution was added, the plates were incubated at $4^{\circ} \mathrm{C}$ for $20 \mathrm{~min}$, and the monocytes were collected by gently scraping with a rubber policeman. For in vitro culture, cells were resuspended at $10^{6} / \mathrm{ml}$ in RPMI 1640 containing $1 \%$ FBS, L-glutamine, and penicillin-streptomycin and plated at $10^{6}$ per well in six-well tissue culture plates.

Synoviocytes. Synoviocytes were isolated from rheumatoid arthritis synovial tissues and cultured as described (21). The cell lines were established from the adherent primary cell populations that contain monocyte- and fibroblast-like cells.

\section{Cell lines}

The human cell lines A549 (lung carcinoma) and U373 (glioblastomaastrocytoma) were obtained from the American Type Culture Collection (Rockville, MD) and maintained in DMEM containing 10\% FBS.

\section{IL-6 bioassay}

The B9 hybridoma proliferation assay was used to measure IL-6 as previously described (21).

\section{Metabolic labeling and immunoprecipitation}

Chondrocytes were maintained in T175 flasks in DMEM containing $10 \%$ FBS, L-glutamine, and antibiotics. For metabolic labeling, cells were plated in 24-well plates at a density of 40,000 cells per well. Before the experiment, cells were serum-starved overnight, washed with PBS, 
and incubated in cysteine- and methionine-free RPMI (ICN Biomedicals, Inc., Costa Mesa, CA ) supplemented with L-glutamine, penicillinstreptomycin, $1 \% \mathrm{FBS},\left[{ }^{35} \mathrm{~S}\right]$ cysteine, and $\left[{ }^{35} \mathrm{~S}\right]$ methionine $(100 \mu \mathrm{Ci} /$ $\mathrm{ml}$; ICN Biomedicals, Inc.) for $48 \mathrm{~h}$. The supernatants were collected and precleared by incubating with protein A Sepharose (Zymed Laboratories, Inc., S. San Francisco, CA) for $1 \mathrm{~h}$. The samples were incubated overnight in the presence of $5 \mu$ l of antibody to IL-6 ( rabbit IgG, $1 \mathrm{mg} / \mathrm{ml}$ ) on a rotor, and protein A Sepharose was added for an additional $2 \mathrm{~h}$. The precipitates were washed five times with PBS containing $0.05 \%$ Tween-80, $0.1 \%$ Triton X-100, and $1 \mathrm{mM}$ PMSF followed by two washes in PBS. The beads were boiled for $5 \mathrm{~min}$ in Laemmli sample buffer and the proteins were separated on $12.5 \%$ polyacrylamide gels under reducing conditions. After staining with Coomassie blue, the gels were treated with Amplify (Amersham Corp., Arlington Heights, IL) for $1 \mathrm{~h}$, dried, and exposed to Kodak XAR film (Eastman Kodak Co., Rochester, NY) at $-70^{\circ} \mathrm{C}$ for $24 \mathrm{~h}$.

\section{$R N A$ probe preparation}

The 600-bp HindIII-DraI fragment of the IL-6 cDNA was inserted into the transcription vector pGEM-3Z (Promega Corp., Madison, WI). The cDNA for IL-8 was kindly provided by Dr. K. Matsushima (Kanazawa University, Ishikawa, Japan). A 500-bp fragment was subcloned into the EcoRI site of pGEM-3z, and its identity with the template cDNA was confirmed by dideoxy sequencing using T7 DNA polymerase (Pharmacia LKB Biotechnology Inc., Piscataway, NJ). For development of a probe for $\beta$-actin, two 15 -base oligonucleotides ( $5^{\prime}$-CGTCGTCGACAACGG-3' and 3'-GACCGTAGCACTACC-5') defining a 438-bp fragment of the cDNA were designed. The restriction sites EcoRI and HindIII were added at their $5^{\prime}$ ends, respectively. After amplification by PCR, the fragment was inserted into pGEM-4z. The recombinant plasmids were linearized and transcribed with the $\mathrm{T} 7$ or SP6 RNA polymerase to obtain antisense probes. The probes were labeled with $\left[{ }^{32} \mathrm{P}\right]$ UTP (Amersham Corp.) and separated from unincorporated nucleotides by gel filtration (Centri-sep columns; Princeton Separations, Adelphia, NJ).

\section{Northern blot hybridization}

Primary chondrocytes were maintained in T175 flasks for 4-7 d. Before stimulation, cells were serum-starved for $24 \mathrm{~h}$. Total RNA was extracted by the single-step guanidinium thiocyanate-phenol-chloroform method (22). 10-30 $\mu$ g of total RNA was separated on $1 \%$ formaldehyde gels, blotted onto nylon filters, and crosslinked with ultraviolet light for $5 \mathrm{~min}$ on each side. The blots were prehybridized in $50 \%$ formamide, $6 \times$ SSC, $0.5 \%$ SDS, $0.1 \%$ Tween- 20 , and $100 \mu \mathrm{gtRNA} / \mathrm{ml}$ for $15 \mathrm{~min}$ at $65^{\circ} \mathrm{C}$. The prehybridization mixture was replaced with fresh solution containing $10^{6} \mathrm{cpm} / \mathrm{ml}$ of probe. Hybridization was performed overnight at $65^{\circ} \mathrm{C}$ and followed by two 30-min washes in $1 \times$ SSC, $0.1 \%$ SDS at room temperature and two 30 -min washes in $0.1 \times$ SSC, $0.1 \%$ SDS at $65^{\circ} \mathrm{C}$. The damp filters were exposed to Kodak XAR film at $-70^{\circ} \mathrm{C}$ for $2-24 \mathrm{~h}$. To confirm equal RNA load and complete transfer the $18 \mathrm{~S}$ and $28 \mathrm{~S}$ bands were visualized with ethidium bromide. In addition, RNA load was examined by probing for $\beta$-actin mRNA.

\section{PCR for cytokines}

Total cellular RNA was isolated from $10^{6}$ cells by the guanidinium thiocyanate phenol chloroform method and used for reverse transcription with M-MLV reverse transcriptase. The cDNA preparations were diluted to different concentrations for the detection of cytokine mRNAs. Glyceraldehyde 3-phosphate dehydrogenase (GAPDH) mRNA served as an internal control to allow comparison of RNA levels between different samples. PCR was performed on an Ericomp temperature cycler in a $50 \mu \mathrm{l}$ reaction volume including $1.25 \mathrm{U}$ taq DNA polymerase, $50 \mathrm{pM}$ of each primer, and $\sim 10 \%$ of the cDNA template. The products of $30-35$ cycles $\left(1 \mathrm{~min}\right.$ at $94^{\circ} \mathrm{C}, 1 \mathrm{~min}$ at $60^{\circ} \mathrm{C}$, and $2 \mathrm{~min}$ at $72^{\circ} \mathrm{C}$ ) were separated by agarose gel electrophoresis and visualized by ethidium bromide staining. The PCR primers for IL- $1 \beta$ were sense: GAG CTC GCC AGT GAA ATG ATG GC (position 16-38) and antisense: GCC CTG AGT GTC GTT TTT TCG AAC (position 402-379), defining a 387-bp fragment. The IL-6 primers were sense: CAC AGA CAG CCA CTC ACC TCT TC (position 4365 ) and antisense: TGT TGA GAT GAG TAA GAC GCG TCG (position 507-484), and resulted in an amplified fragment of $465 \mathrm{bp}$. The primers for GAPDH were sense: TGG TAT CGT GGA AGG ACT CAT GAC and antisense: ATG CCA GTG AGC TTC CCG TTC AGC, defining a 190-bp fragment. In some studies PCR was performed with [ $\left.{ }^{32} \mathrm{P}\right] \mathrm{dCTP}$ in 25 cycles, which in separate experiments was shown to be within the linear range of amplification for both IL-6 and GAPDH. PCR products were separated on $8 \%$ acrylamide gels. The IL- 6 and GAPDH bands were cut out and solubilized in scintillation liquid, and radioactivity was counted.

\section{Reagents}

The following reagents were used: IL- $1 \beta$, LIF, and rabbit antibody to human IL-6 (R\&D Systems, Inc., Minneapolis, MN). Endotoxin content of the cytokine preparations was $<0.1 \mathrm{ng}$ per $1 \mu \mathrm{g}$ of IL-1 or LIF protein. LPS from Salmonella Minnesota and PMA (Sigma Immunochemicals).

\section{Results}

LIF induces $I L-6$ and $I L-8 m R N A$ expression in chondrocytes. Primary human articular chondrocytes were serum-starved for $24 \mathrm{~h}$ to avoid interference of serum components with mRNA induction by the specific cytokines. Cells were then stimulated with LIF and RNA was analyzed by Northern blotting. Fig. $1 \mathrm{~A}$ shows that IL-6 and IL-8 mRNA are not detected in unstimulated chondrocytes. Stimulation with LIF for $4 \mathrm{~h}$ caused a dosedependent induction of both cytokines. The IL-6 and IL-8 mRNAs had the expected sizes of 1.3 and $1.7 \mathrm{~kb}$, respectively. LIF effects on IL-6 and IL-8 mRNAs are already detectable 1.3 $\mathrm{h}$ after stimulation (Fig. $1 \mathrm{~B}$ ) and levels increase further for $5 \mathrm{~h}$.

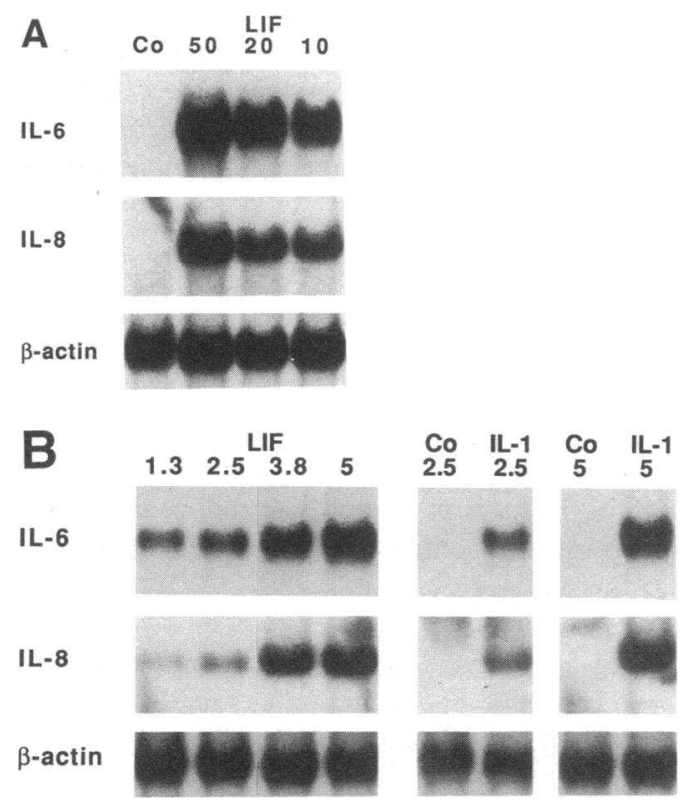

Figure 1. LIF induces IL-6 and IL-8 mRNA expression in chondrocytes. Primary human articular chondrocytes were serum-starved and left in media alone ( $\mathrm{Co}$, control) or stimulated with LIF or IL- $1 \beta$ for $4 \mathrm{~h}(A) . B$ shows RNA from cells that were stimulated with IL- $1 \beta$ or LIF for the time periods indicated in hours above the lanes. Total cellular RNA was analyzed for IL-6 and IL-8 expression by Northern blotting. The same filters were subsequently probed for $\beta$-actin to document the amount of RNA loaded. 


\section{9 IL1ß-

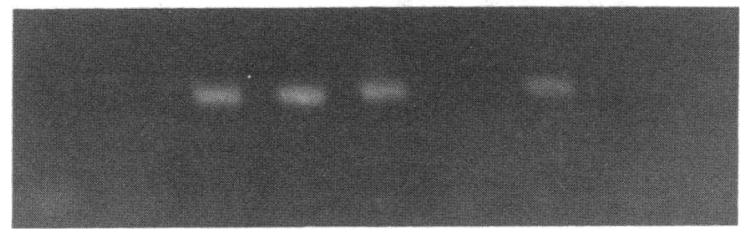

\section{GPDH -}

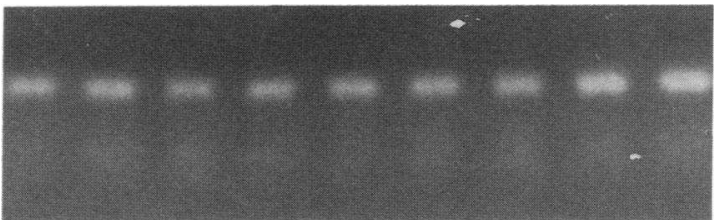

Figure 2. Regulation of IL-1 $\beta$ expression in chondrocytes. Primary articular chondrocytes were stimulated in serum-free media for $4 \mathrm{~h}$ with cytokines and growth factors. RNA was isolated and cDNA was prepared by reverse transcription and amplified by PCR in the presence of IL- $1 \beta$-specific primers. Aliquots of the same chondrocyte cDNA were amplified in the presence of primers for GAPDH (to serve as a control for the amount of template in the different samples). PCR products were separated on agarose gels, stained with ethidium bromide, and visualized under ultraviolet light. Lane $1,10 \mathrm{ng} / \mathrm{ml}$ PDGF; lane $2,10 \mathrm{ng} / \mathrm{ml}$ bFGF; lane $3,10 \mathrm{ng} / \mathrm{ml} \mathrm{IL-1} \beta$; lane $4,10 \mathrm{ng} / \mathrm{ml}$ IL-6; lane $5,10 \mathrm{ng} / \mathrm{ml} \mathrm{LIF;} \mathrm{lane} 6,10 \mathrm{ng} / \mathrm{ml}$ TGF- $\beta 1$; lane 7, $500 \mathrm{U} / \mathrm{ml} \mathrm{TNF} \alpha$; lane $8,5 \% \mathrm{FBS}$; lane 9 , serum-free media control.
IL- $1 \beta$ is a well-characterized and potent inducer of IL-6 and IL-8 in chondrocytes (23). Fig. $1 B$ shows the results of a comparative analysis of LIF and IL- $1 \beta$. After 2.5 or $5 \mathrm{~h}$ stimulation, LIF induced quantitatively increases in IL-6 and IL-8 mRNA levels similar to IL- $1 \beta$.

Although IL-1 is an important regulator of chondrocyte function, it is not clear whether chondrocytes express the IL-1 gene. We thus analyzed IL- $1 \beta$ mRNA expression in chondrocytes. Fig. 2 shows that IL- $1 \beta$ mRNA is readily detectable in activated primary human articular chondrocytes. Only a faint signal is seen in unstimulated cells, but this is markedly increased after chondrocyte activation with cytokines. IL- $1 \beta$ mRNA levels were induced by IL- $1 \beta$, and this is consistent with IL-1 autoinduction, which has been demonstrated in other cell types. Chondrocyte stimulation with LIF caused a similar increase in IL- $1 \beta$ gene expression. Fig. 2 also shows that IL-6 can induce IL- $1 \beta$ mRNA in chondrocytes, while the growth factors TGF $\beta$, PDGF, and bFGF have no detectable effect. These results show that LIF induces IL-6, IL-8, and IL$1 \beta$ mRNA in primary chondrocytes and that the magnitude and kinetics of its effects are similar to those of IL- $1 \beta$.

LIF effects on IL-6 expression in human blood monocytes. LIF regulates differentiation of myeloid leukemia cells and mononuclear phagocytes express LIF receptors (24). As monocytes are an important source of cytokines, we tested whether LIF can induce the expression of proinflammatory cytokines in this cell type. Fig. 3 shows the results from PCR analysis for IL-6 expression. Low levels of IL-6 mRNA were detected in adherent monocytes. A strong increase was seen with LPS, a known inducer of IL-6. LIF dose dependently stimulated IL-6 mRNA levels. LIF effects were already apparent by $2 \mathrm{~h}$ and started to decline by $5 \mathrm{~h}$. The increase in steady-state IL-6 mRNA levels by LIF was greater than that induced by IL- $1 \beta$ in the same dose range.

PCR analysis with ${ }^{32} \mathrm{P}$-labeled nucleotides showed that IL-6 mRNA increase $\sim 10$-fold in the presence of LIF at 50 and 10 $\mathrm{ng} / \mathrm{ml}$ under conditions where the levels of GAPDH radiolabeled PCR product were constant (not shown). Sequencing of PCR product that was obtained with the IL-6 primers confirmed that it had the expected nucleotide composition of the IL-6 gene between positions 43 and 507.

IL-6 is de novo synthesized in response to LIF. Having shown that LIF can induce cytokine mRNA expression, we analyzed whether gene expression resulted in a corresponding increase in protein synthesis. Subcultured (passage 1) or primary chondrocytes were serum-starved for $24 \mathrm{~h}$ and then stimulated with LIF at concentrations between 10 and $50 \mathrm{ng} / \mathrm{ml}$. Conditioned media were harvested after $48 \mathrm{~h}$ and IL- 6 was immunoprecipitated and analyzed by SDS-PAGE. The effects of IL- $1 \beta$ are shown for comparison. In both cell populations (subcultured cells, lanes 1-5; primary chondrocytes, lanes 6-10) LIF induced dose-dependent synthesis and secretion of IL- 6 proteins which were detected as the characteristic bands between 20 and $30 \mathrm{kD}$, representing the different molecular forms of IL-6 (Fig. 4). The relative intensity of these bands is similar in IL- $1 \beta$ - or LIF-treated cells. Thus, LIF not only leads

\section{$\begin{array}{llllllllllll}1 & 2 & 3 & 4 & 5 & 6 & 7 & 8 & 9 & 10 & 11 & 12\end{array}$}

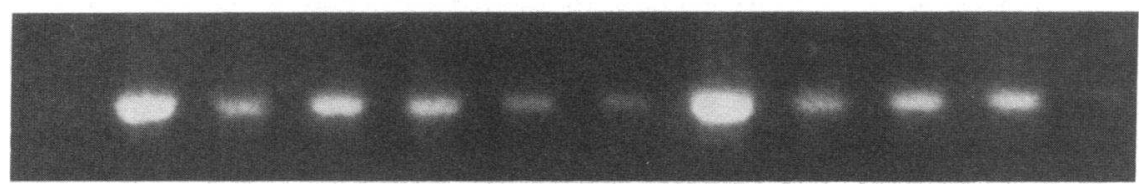

Figure 3. LIF induces IL-6 m RNA expression in monocytes. Monocytes were stimulated with LIF, IL-1 $\beta$, or LPS for 2 or $4 \mathrm{~h}$. IL-6 mRNA was measured by PCR as described in Fig. 2 . Lanes 1 and 7, unstimulated; lanes 2 and 8 , $1 \mu \mathrm{g} / \mathrm{ml} \mathrm{LPS}$; lanes 3 and 9, $10 \mathrm{ng} / \mathrm{ml} \mathrm{IL-1;}$ lanes 4 and $10,50 \mathrm{ng} / \mathrm{ml} \mathrm{LIF;} \mathrm{lanes} 5$ and 11 , $10 \mathrm{ng} / \mathrm{ml} \mathrm{LIF}$; lanes 6 and $12,1 \mathrm{ng} / \mathrm{ml} \mathrm{LIF}$;

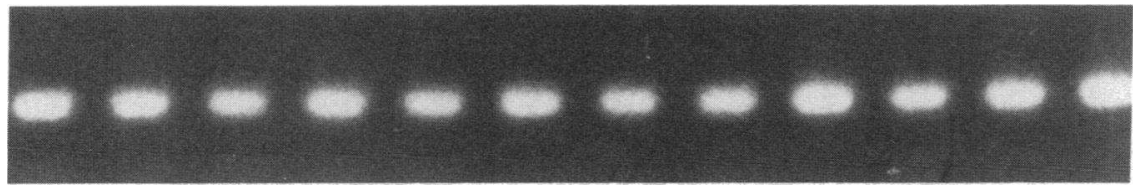
lanes $1-6$, stimulation for $2 \mathrm{~h}$; lanes $7-12$, stimulation for $4 \mathrm{~h}$. Upper panel shows the IL6 PCR product. Lower panel shows the result from amplification of aliquots of the same chondrocyte cDNA for GAPDH. 


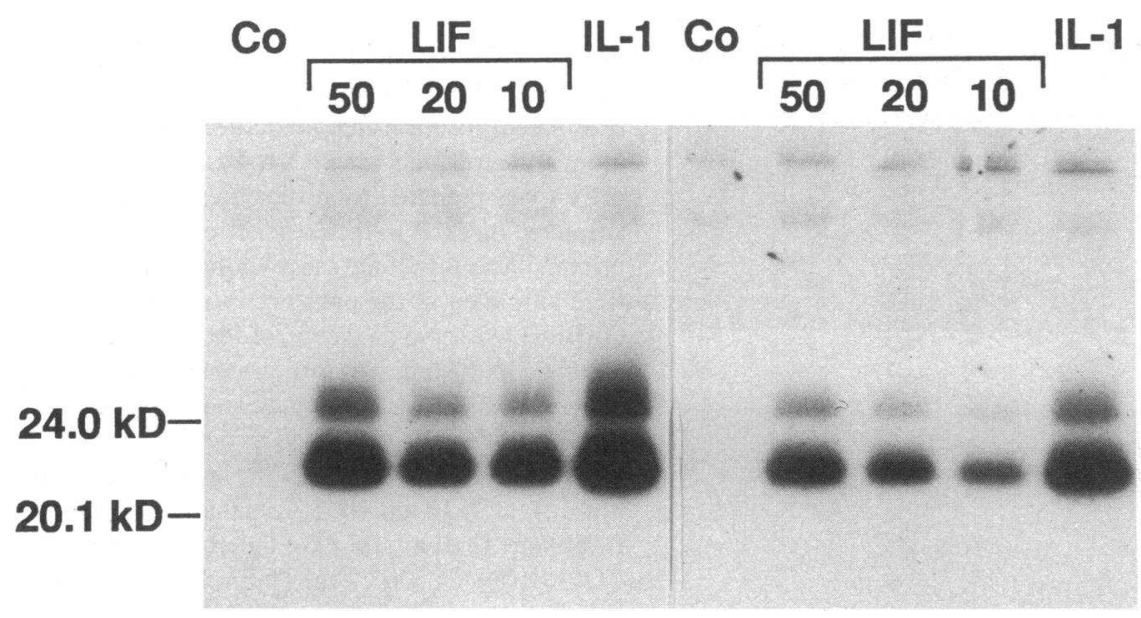

Figure 4. IL-6 synthesis and release by LIFtreated chondrocytes. Human articular chondrocytes as primary (left) or subcultured (right) cells were stimulated with LIF (concentrations in nanograms per milliliter) or IL$1 \beta(1 \mathrm{ng} / \mathrm{ml})$ and metabolically labeled for 48 h. Cells cultured in media alone were included as control $(\mathrm{Co})$. IL-6 was immunoprecipitated from conditioned media and separated on SDS-PAGE under reducing conditions. Gels were dried and newly synthesized IL-6 proteins were visualized by autoradiography.

to a rapid expression of IL- 6 mRNA but it also induces synthesis and secretion of IL- 6 proteins.

LIF increases IL-6 bioactivity in conditioned media. To test whether IL- 6 in conditioned media from LIF-treated cells was biologically active, IL-6 activity was measured in the B9 hybridoma proliferation assay. LIF induced a dose-related increase in IL- 6 bioactivity in 24-h chondrocyte cultures to levels similar to those found in IL-1 $\beta$-stimulated cultures (Fig. 5). At lower doses $(0.1 \mathrm{ng} / \mathrm{ml}) \mathrm{IL}-1 \beta$ appeared to be more potent than LIF.

Low levels of IL-6 activity were found in 24-h conditioned media from adherent blood monocyte cultures. LIF caused a maximal 10.5-fold increase in IL-6 levels. The maximal IL- $1 \beta$ effect was a 13.4-fold stimulation of IL-6. Collectively, these results show that LIF induces synthesis and secretion of biologically active IL-6 in monocytes and chondrocytes.

Since LIF can stimulate IL-1 expression and IL-1 is a potent inducer of IL-6, it was possible that the LIF effect was dependent on IL-1. Fig. 6 shows that the LIF induction was almost completely inhibited by antibody to LIF but not by anti-IL-1 or preimmune rabbit IgG. The antibody to IL-1 was biologically active since it was able to reduce the IL-1 effect on IL-6 expression. These findings suggest that the induction of IL-6 is a direct function of LIF. In addition, these results also demonstrate that the induction of IL- 6 was not due to the presence of endotoxin in the LIF preparation used.

LIF induction of cytokines in other cell types. To determine whether the effects of LIF on cytokine expression are restricted to particular cell types or represent a general response in different tissues, human rheumatoid synoviocytes, glioblastoma, and lung epithelial cells were stimulated with LIF and probed for the expression of different cytokine mRNAs. LIF induced a dose-related increase in IL-6 mRNA expression in synoviocytes, in the epithelial cell line A549, and in the glioblastoma cell line U373 (Fig. 7). The increase in mRNA levels in all cell lines induced by LIF and IL- $1 \beta$ was of similar magnitude. LPS had only weak or no effects on IL-6 expression in synoviocytes and A549 and U373 cells, which suggests that the ability of LIF to induce cytokine mRNAs is not due to the presence of small amounts of endotoxin. In addition to IL-6, LIF also induced the expression of mRNAs for IL- $1 \beta$ and the monocyte chemoattractant protein-1 in these different cell types (not shown).
For better quantification of the LIF effects on IL-6 mRNA levels, PCR for IL-6 and GAPDH was performed in the presence of $\left[{ }^{32} \mathrm{P}\right] \mathrm{dCTP}$ for 25 cycles, which in separate experiments was shown to be within the linear range of amplification for both IL-6 and GAPDH. The results in Fig. 8, which were normalized on the basis of the counts for GAPDH, show that LIF caused a dose-dependent increase in IL-6 mRNA which was 10.3-, 11.2-, and 2.7-fold, respectively, at the three different concentrations of LIF used.

\section{Discussion}

This study shows that LIF induces expression of proinflammatory cytokines. Human articular chondrocytes express IL- $1 \beta$, IL-6, and IL-8 mRNA and synthesize and secrete biologically active IL-6 in response to LIF. Similar effects were found in human blood monocytes, synoviocytes, and epithelial and neuronal cell lines. Through the induction of these cytokines in diverse cell types LIF has the potential to initiate and propagate inflammatory and immunological responses.

LIF is a cytokine that regulates differentiation of a wide variety of cell types including embryonic stem cells and hematopoietic and neuronal cells (25). More recently, it was recognized that LIF also regulates bone metabolism in vitro and in vivo (9-11) and that it induces expression of hepatic acute phase proteins (4). Other functions include the inhibition of lipoprotein lipase activity (8) and the increase in neuronal substance P (SP) expression (26).

Although LIF does not share sequence homology with IL-6, these two cytokines have some similar functional properties. Both augment proliferation of hematopoietic stem cells (27) and induce differentiation of murine M1 leukemic cells (28). Furthermore, IL-6 and LIF induce expression of a similar set of acute phase proteins in hepatocytes $(4,29)$. These findings could be explained by a reciprocal induction of the two cytokines, but in hematopoietic cells this mechanism has been ruled out using neutralizing antibodies (27). Another explanation for functional similarities is the possibility that LIF and IL-6 stimulate similar intracellular signals. This hypothesis was supported by the characterization of the LIF receptor (30), which has structural homology with the IL-6 signal transducer, gp130. Furthermore, the same immediate early pattern of gene expression has been observed upon induction of myeloid leu- 

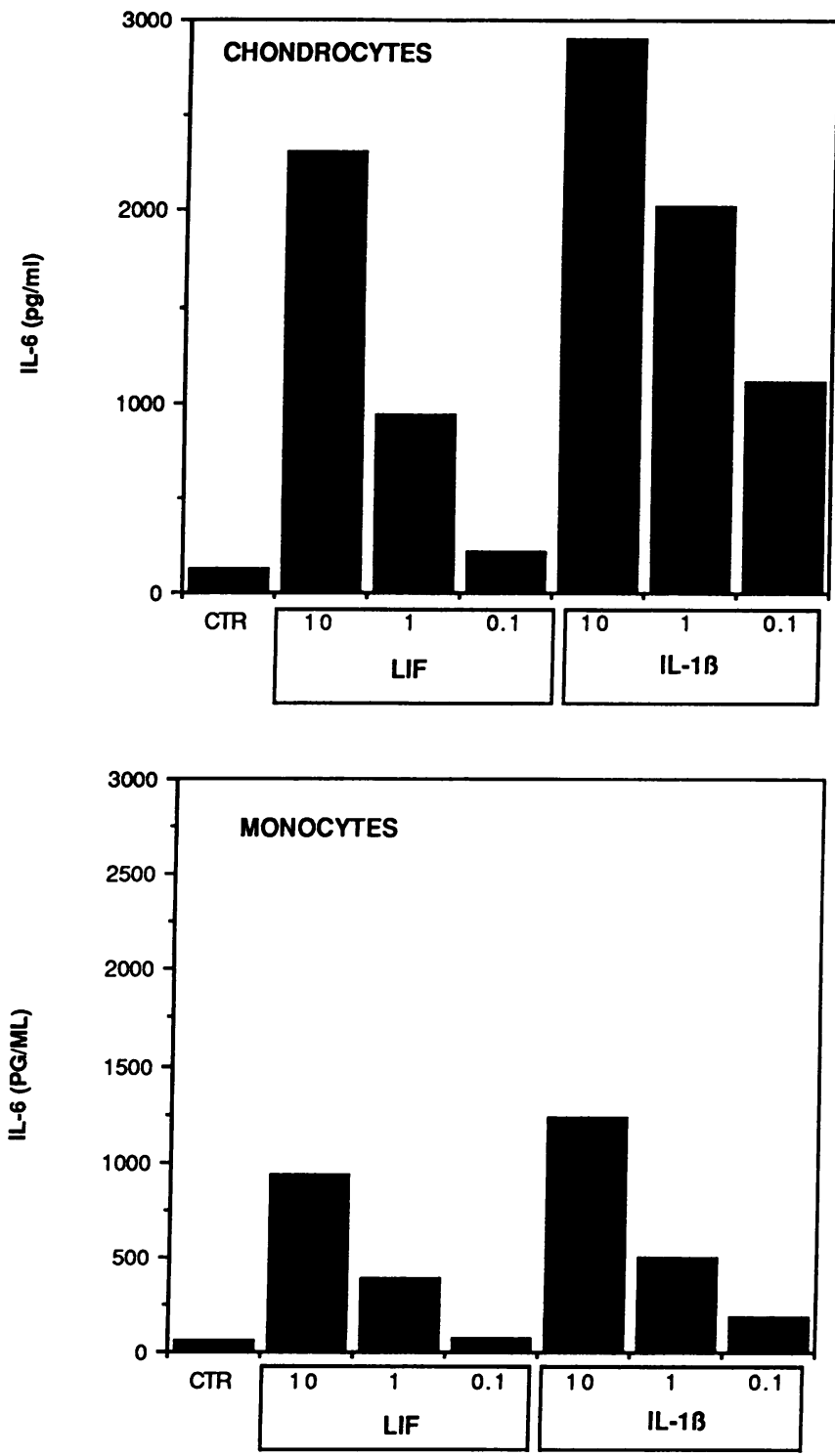

Figure 5. Chondrocytes and monocytes secrete biologically active IL6 in response to LIF. Conditioned media were collected from 24-h cultures of cytokine-stimulated chondrocytes and monocytes. Concentrations of IL- $1 \beta$ and LIF are shown in nanograms per milliliter. The samples were tested in the $\mathrm{B} 9$ hybridoma proliferation assay for IL- 6 activity. IL- 6 was quantified on the basis of a standard curve using recombinant human IL-6. Results are expressed as mean values from one representative experiment (total number of experiments $=4$ ) performed in triplicate.

kemia cell differentiation by IL-6 and LIF (31). Oncostatin M (OSM) (32) has effects similar to those of IL-6 and LIF on hepatocytes and murine myeloid leukemia cells and, although this has not been formally demonstrated, it is conceivable that other cell types show similar responses to LIF and OSM. This notion is based on the recent demonstration that the high affinity receptor for LIF, which is composed of the IL-6 signal transducer gp 130 and the LIF receptor- $\alpha$ chain, is also a high affinity OSM receptor (33).

IL-1 and IL-6 share some biological effects, but there are also important functional differences. These include the induc-

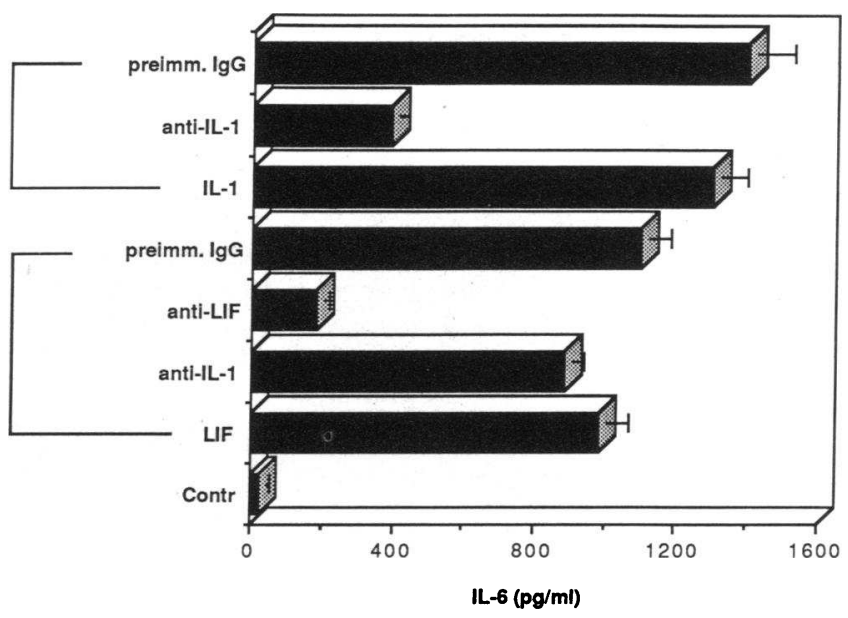

Figure 6. LIF induction of IL-6 is not IL-1 dependent. $5 \mathrm{ng} / \mathrm{ml} \mathrm{LIF}$ or $1 \mathrm{ng} / \mathrm{ml} \mathrm{IL-1}$ was preincubated with specific neutralizing antibody or preimmune rabbit IgG (all at $10 \mu \mathrm{g} / \mathrm{ml}$ ) or in media only. These mixtures of cytokines and antibodies and LIF or IL-1 that had not been pretreated with antibody were then added to chondrocyte cultures. IL-6 activity in 24-h conditioned media was determined in the B9 assay. Results represent mean \pm SEM of two experiments performed in triplicate.

tion of proteases by IL-1 (34) but the induction of protease inhibitors by IL-6 (35) or a marked difference in the induction of other proinflammatory cytokines. IL-1 but not IL- 6 induces IL-8 and monocyte chemoattractant protein-1 (MCP-1) (23, 36). Although LIF shares functional properties with IL-6, several findings indicate that the quality of the LIF effects is more proinflammatory and similar to IL-1. LIF inhibits lipoprotein lipase activity (8), which can lead to cachexia (10). IL-1 and LIF, but not IL-6, increase neuronal SP expression (26). We recently showed that LIF induces expression of collagenase and stromelysin by human articular chondrocytes, and that it does not stimulate the expression of tissue inhibitor of metalloproteinases (Lotz, M., P. M. Villiger, R. Melton, and V. Ganu, manuscript in preparation). Furthermore, LIF, but not IL-6, induces expression of MCP-1 in chondrocytes (36). This study provides evidence that the proinflammatory actions of LIF include induction of the cytokines IL-1 and IL- 6 as well as the neutrophil chemoattractant protein IL-8. These findings strongly support the notion that LIF can directly and indirectly initiate inflammatory events and suggest a synergy between LIF and IL-1 since both cytokines can induce each other's expression.

Arthritis is one example of many diseases where this LIF effect can contribute to pathogenesis. Cartilage is the final target of joint inflammation. Independent from the underlying disease processes, inflammation results in destruction of cartilage leading to impairment of joint function and arthrosis. Chondrocytes are now known to actively participate in regulation of inflammatory reactions through the production of a broad range of cytokines and growth factors $(20,23,36,37)$. It was not clear whether chondrocytes also produce IL-1, which is a critical catabolic factor for cartilage since it inhibits the synthesis of glucosaminoglycans and stimulates the production of metalloproteinases. We show here that chondrocytes indeed express the IL- $1 \beta$ gene and that IL- 1 can autoinduce its mRNA in this cell type. More importantly, LIF induces IL- $1 \beta$ in chon- 


\section{Synov. Chond. A549 U373}

\section{6}

\section{IL-6}

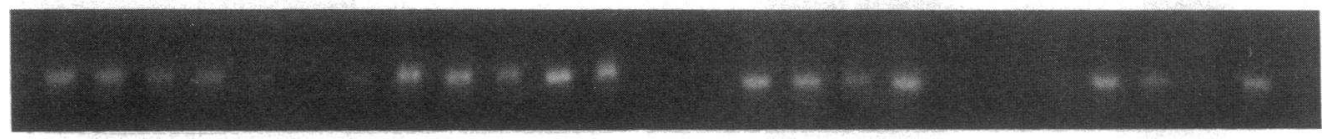

\section{GPDH}

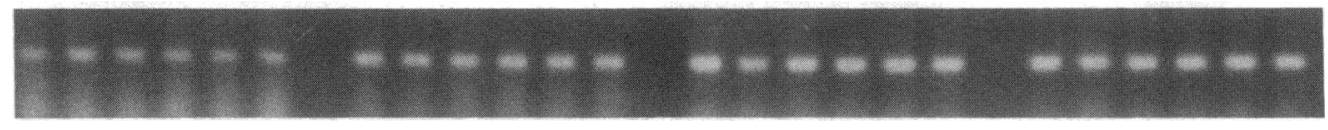

Figure 7. Effects of LIF on cytokine mRNA expression in different cell types. A549 cells, U373 cells, chondrocytes, and human rheumatoid synoviocytes were plated in six-well plates, grown to confluency, and serum-starved for $48 \mathrm{~h}$. The cells were then stimulated with LIF or IL-1 $\beta$ for $4 \mathrm{~h}$. RNA was extracted and analyzed for IL-6 mRNA levels by PCR. Lane 1 , control; lane 2, $50 \mathrm{ng} / \mathrm{ml} \mathrm{LIF;} \mathrm{lane} \mathrm{3,} 10 \mathrm{ng} / \mathrm{ml} \mathrm{LIF;} \mathrm{lane} \mathrm{4,}$ $1 \mathrm{ng} / \mathrm{ml} \mathrm{LIF}$; lane $5,10 \mathrm{ng} / \mathrm{ml}$ IL-1 $\beta$; lane $6,100 \mathrm{ng} / \mathrm{ml}$ LPS.

drocytes. Thus, LIF can directly stimulate cartilage destruction via the induction of proteinases and indirectly through the induction of IL-1. Cartilage thus is a source of two cytokines that induce connective tissue catabolism. The function of these two cytokines is potentiated since they induce each other's as well as their own production (20). This complex interaction of the two cytokines raises the possibility that the effect of one may be mediated via the induction of the other factor. However, the rapid induction of IL- 6 and IL- 8 by IL- 1 and LIF which occurs within $2 \mathrm{~h}$, and the fact that antibody to IL-1 did not inhibit LIF-induced IL-6 production, suggest that these are probably direct LIF effects. This was supported by experiments where neutralizing antibody to IL- $1 \beta$ did not inhibit the induction of IL- 6 by LIF.

LIF is also expressed by synovial tissue cells. We recently found expression of high levels of LIF mRNA in response to stimulation with IL-1 in synovial organ culture (20) where mRNA was primarily localized in interstitial cells. For the analysis of LIF effects on cytokine expression in synoviocytes we did not detect constitutive levels of cytokine mRNAs, which can be found in freshly isolated rheumatoid synovium. In this study we used cells that had been cultured in the absence of serum for $24-48 \mathrm{~h}$ to avoid contribution of serum factors to the LIF effect on the induction of other cytokines. As LIF can induce expression of the two chemoattractant proteins, IL-8 and MCP-1, an indirect role of LIF in recruitment of inflammatory cells which are typically present in joint inflammation can be proposed. Furthermore, LIF could enhance the proinflammatory functions of the invading monocytes as it induces cytokine expression in these cells.

With its effects on chondrocytes and synoviocytes LIF can contribute to pathogenesis of arthritis. However, through the ability to stimulate cytokine production in mononuclear phagocytes, LIF is a pathogenetic mediator in diverse disease states. LIF had originally been described as an inducer of monocyte differentiation of the murine M1 myeloid leukemia cell line (1). However, although LIF receptors have been found on macrophages, monocytes, and their precursors (24), no effect of LIF on mature monocytes has been described. The present findings of LIF induction of IL-6 mRNA and IL-6 activity are the first demonstration of LIF effects on mature monocytes.
Based on these findings we have more recently shown that LIF can also stimulate HIV replication in mononuclear phagocytes (Broor, S., A. B. Kusari, B. Zhang, P. Seth, D. D. Richman, D. A. Carson, W. Wachsman, and M. Lotz, manuscript in preparation). The ability of LIF to stimulate cytokine expression appears not to be restricted to a particular cell type. In addition to chondrocytes and monocytes, we observed similar effects in synoviocytes and epithelial and neuronal cell lines, which suggests that LIF is a ubiquitous inducer of cytokines.

In summary, LIF is a potent inducer of cytokines such as IL-1 $\beta$, IL-6, MCP-1, and IL-8 in a broad spectrum of cell types. Through these effects that have thus far only been identified for IL-1 and TNF, LIF can regulate inflammatory and immune responses and promote connective tissue catabolism. LIF thus

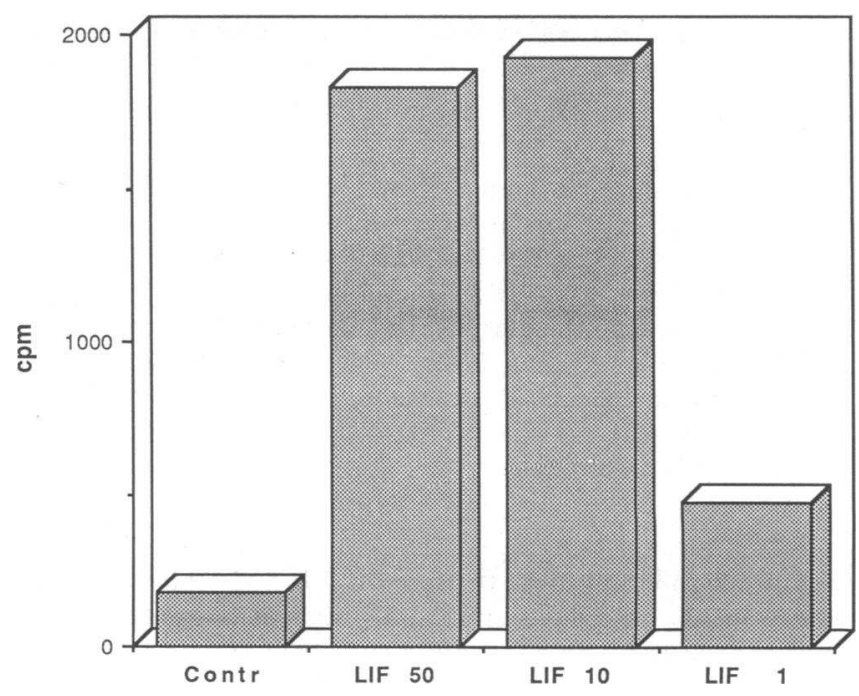

Figure 8. Quantification of LIF effects on IL-6 mRNA expression. Chondrocytes were stimulated for $4 \mathrm{~h}$ with LIF in the concentrations indicated (nanograms per milliliter). RNA was isolated and PCR was performed for IL-6 and GAPDH in the presence of [ $\left.{ }^{32} \mathrm{P}\right] \mathrm{dCTP}$. The PCR products were separated on acrylamide gels and excised, and radioactivity was quantified by scintillation counting. Results are shown as counts per minute of IL-6 PCR product, which were normalized on the basis of the counts for GAPDH. 
has the potential to be a pathogenetic mediator in diverse disease states.

\section{Acknowledgments}

We thank Jacqueline Quach and Jinae Shin for expert technical assistance. Drs. Kurt Benirschke, Paul Wolff, and Glenn Greenleaf provided the cartilage samples that were used in this study.

This work was supported by National Institutes of Health grants AR-39799, AG-07996, and RR-00833.

\section{References}

1. Hilton, D. J., N. A. Nicola, N. M. Gough, and D. Metcalf. 1988. Resolution and purification of three distinct factors produced by Krebs ascites cells which have differentiation-inducing activity on murine myeloid leukemic cell lines. $J$. Biol. Chem. 263:9238-9243.

2. Williams, R. L., D. J. Hilton, S. Pease, T. A. Willson, C. L. Stewart, D. P. Gearing, E. F. Wagner, D. Metcalf, N. A. Nicola, and N. M. Gough. 1988. My eloid leukaemia inhibitory factor maintains the developmental potential of embryonic stem cells. Nature (Lond.). 336:684-687.

3. Smith, A. G., J. K. Heath, D. D. Donaldson, G. G. Wong, J. Moreau, M. Stahl, and D. Rogers. 1988. Inhibition of pluripotential embryonic stem cell differentiation by purified polypeptides. Nature (Lond.). 336:688-690.

4. Baumann, H., and G. G. Wong. 1989. Hepatocyte-stimulating factor III shares structural and functional identity with leukemia-inhibitory factor. $\mathrm{J}$. Im munol. 143:1163-1167.

5. Yamamori, T., K. Fukada, R. Aebersold, S. Korsching, M. J. Fann, and P. H. Patterson. 1989. The cholinergic neuronal differentiation factor from hear cells is identical to leukemia inhibitory factor. Science (Wash. DC). 246:14121416.

6. Yamamori, T. 1991. Localization of cholinergic differentiation factor/leukemia inhibitory factor mRNA in the rat brain and peripheral tissues. Proc. Natl. Acad. Sci. USA 88:7298-7302.

7. Murphy, M., K. Reid, D. J. Hilton, and P. F. Bartlett. 1991. Generation of sensory neurons is stimulated by leukemia inhibitory factor. Proc. Natl. Acad. Sci. USA. 88:3498-3501.

8. Mori, M., K. Yamaguchi, and K. Abe. 1989. Purification of a lipoprotein lipase-inhibiting protein produced by a melanoma cell line associated with cancer cachexia. Biochem. Biophys. Res. Commun. 160:1085-1092.

9. Abe, E., H. Tanaka, Y. Ishimi, C. Miyaura, T. Hayashi, H. Nagasawa, M. Tomida, Y. Yamaguchi, M. Hozumi, and T. Suda. 1986. Differentiation-inducing factor purified from conditioned medium of mitogen-treated spleen cell cultures stimulates bone resorption. Proc. Natl. Acad. Sci. USA 83:5958-5962.

10. Metcalf, D., and D. P. Gearing. 1989. Fatal syndrome in mice engrafted with cells producing high levels of the leukemia inhibitory factor. Proc. Natl. Acad. Sci. USA 86:5948-5952.

11. Reid, L. R., C. Lowe, J. Cornish, S. J. Skinner, D. J. Hilton, T. A. Willson, D. P. Gearing, and T. J. Martin. 1990. Leukemia inhibitory factor: a novel boneactive cytokine. Endocrinology. 126:1416-1420.

12. Godard, A., H. Gascan, J. Naulet, M.-A. Peyrat, Y. Jacques, J.-P. Soulillou, and J. F. Moreau. 1988. Biochemical characterization and purification of HILDA, a human lymphokine active on eosinophils and bone marrow cells. Blood. 71:1618-1623.

13. Anegon, I., J. F. Moreau, A. Godard, Y. Jacques, M. A. Peyrat, M. M. Hallet, G. Wong, and J. P. Soulillou. 1990. Production of human interleukin for DA cells (HILDA)/leukemia inhibitory factor (LIF) by activated monocytes: production of human interleukin for DA cells (HILDA)/leukemia inhibitory factor (LIF) by activated monocytes. Cell. Immunol. 130:50-65.

14. Le, P. T., S. Lazorick, L. P. Whichard, Y. C. Yang, S. C. Clark, B. F. Haynes, and K. H. Singer. 1990. Human thymic epithelial cells produce IL-6, granulocyte- monocyte-CSF, and leukemia inhibitory factor. J. Immunol. 145:3310-3315.

15. Tomida, M., Y. Yamamoto-Yamaguchi, and M. Hozumi. 1984. Purification of a factor inducing differentiation of mouse myeloid leukaemic M1 cells from conditioned medium of mouse fibroblast L929 cells. J. Biol. Chem. 259:10978-10982.
16. Koopman, P., and R. G. H. Cotton. 1984. A factor produced by feeder cells which inhibits embryonal carcinoma cell differentiation: characterization and partial purification. Exp. Cell Res. 154:233-242.

17. Lubbert, M., L. Mantovani, A. Lindemann, R. Mertelsmann, and F. Herrmann. 1991. Expression of leukemia inhibitory factor is regulated in human mesenchymal cells. Leukemia (Baltimore) . 5:361-365.

18. Smith, A. G., and M. L. Hooper. 1987. Buffalo rat liver cells produce a diffusible activity which inhibits the differentiation of murine embryonal carcinoma and embryonic stem cells. Dev. Biol. 12:1-9.

19. Gascan, H., I. Anegon, V. Praloran, J. Naulet, A. Godard, J. P. Soulillou, and Y. Jacques. 1990. Constitutive production of human interleukin for DA cells/leukemia inhibitory factor by human tumor cell lines derived from various tissues. J. Immunol. 144:2592-2598.

20. Lotz, M., T. Moats, and P. M. Villiger. 1992. Leukemia inhibitory factor is expressed in cartilage and synovium. Potential contributions to the pathogenesis of arthritis. J. Clin. Invest. 90:888-896.

21. Guerne, P.-A., B. L. Zuraw, J. H. Vaughan, D. A. Carson, and M. Lotz. 1989. Synovium as a source of interleukin-6 in vitro. Contribution to local and systemic manifestations of arthritis. J. Clin. Invest. 83:585-592.

22. Chomczynski, P., and N. Sacchi. 1987. Single-step method of RNA isolation by acid guanidinium thiocyanate-phenol-chloroform extraction. Anal. Biochem. 162:156-159.

23. Lotz, M., R. Terkeltaub, and P. M. Villiger. 1992. Chondrocytes and joint inflammation: expression of IL-8 in response to peptide regulatory factors and proinflammatory agents. J. Immunol. 148:466-496.

24. Hilton, D. J., N. A. Nicola, and D. Metcalf. 1988. Specific binding of murine leukemia inhibitory factor to normal and leukemic monocytic cells. Proc. Natl. Acad. Sci. USA 85:5971-5975.

25. Gough, N. M., and R. L. Williams. 1989. The pleiotropic actions of leukemia inhibitory factor. Cancer Cells (Cold Spring Harbor). 1:77-80.

26. Freidin, M., and J. A. Kessler. 1991. Cytokine regulation of substance $P$ expression in sympathetic neurons. Proc. Natl. Acad. Sci. USA. 88:3200-3203.

27. Leary, A. G., G. G. Wong, S. C. Clark, A. G. Smith, and M. Ogawa. 1990. Leukemia inhibitory factor differentiation-inhibiting activity/human interleukin for DA cells augments proliferation of human hematopoietic stem cells. Blood. 75:1960-1964.

28. Metcalf, D. 1989. Actions and interactions of G-CSF, LIF, and IL-6 on normal and leukemic murine cells. Leukemia (Baltimore). 3:349-355.

29. Kordula, T., H. Rokita, A. Koj, W. Fiers, J. Gauldie, and H. Baumann. 1991. Effects of interleukin-6 and leukemia inhibitory factor on the acute phase response and DNA synthesis in cultured rat hepatocytes. Lymphokine Res. 10:23-26.

30. Gearing, D. P., C. J. Thut, T. VandeBos, S. D. Gimpel, P. B. Delaney, J. King. V. Price, D. Cosman, and M. P. Beckmann. 1991. Leukemia inhibitory factor receptor is structurally related to the IL-6 signal transducer, gp 130. EMBO (Eur. Mol. Biol. Organ.) J. 10:2839-2848.

31. Lord, K. A., A. Abdollahi, S. M. Thomas, M. DeMarco, J. S. Brugge, B. Hoffman-Liebermann, and D. A. Liebermann. 1991. Leukemia inhibitory factor and interleukin- 6 trigger the same immediate early response, including tyrosine phosphorylation, upon induction of myeloid leukemia differentiation. Mol. Cell. Biol. 11:4371-4379.

32. Rose, T. M., and A. G. Bruce. 1991. Oncostatin M is a member of a cytokine family that includes leukemia-inhibitory factor, granulocyte colonystimulating factor, and interleukin-6. Proc. Natl. Acad. Sci. USA. 88:8641-8645.

33. Gearing, D. P., M. R. Comeau, D. J. Friend, S. D. Gimpel, C. J. Thut, J. McGourty, K. K. Brasher, J. A. King, S. Gillis, B. Mosley, S. F. Ziegler, and D. Cosman. 1992. The IL-6 signal transducer, gp 130: and oncostatin M receptor and affinity converter for the LIF receptor. Science (Wash. DC). 255:1434-1437.

34. Mizel, S. B., J. M. Dayer, S. M. Krane, and S. E. Mergenhagen. 1981. Stimulation of rheumatoid synovial cell collagenase and prostaglandin production by partially purified lymphocyte activating factor (interleukin-1 ). Proc. Natl. Acad. Sci. USA. 78:2474-2477.

35. Lotz, M., and P. A. Guerne. 1991. Interleukin-6 induces the synthesis of tissue inhibitor of metalloproteinases-1/erythroid potentiating activity (TIMP1/EPA). J. Biol. Chem. 266:2017-2020.

36. Villiger, P., R. Terkeltaub, and M. Lotz. 1992. Monocyte chemoattractant protein-1 (MCP-1) expression in human articular cartilage. Induction by peptide regulatory factors and differential effects of dexamethasone and retinoic acid. $J$. Clin. Invest. 90:488-496.

37. Guerne, P. A., D. A. Carson, and M. Lotz. 1990. IL-6 production by human articular chondrocytes: modulation of its synthesis by cytokines, growth factors, and hormones in vitro. J. Immunol. 144:499-505. 